\title{
Irrigated Area and Water Utilization of Mula Irrigation Project in Ahmednagar District: A Geographical Study
}

\author{
Dr. Gajhans D. S. ${ }^{1}$ Dr. Suryawanshi M. V. ${ }^{2}$, Ausarmal D. V. ${ }^{3}$ \\ ${ }^{1}$ Associate Professor, Dept. of Geography, M.S.S College, Jalana \\ ${ }^{2}$ Head of Department, Dr. B. A. M. University, Aurangabad \\ ${ }^{3}$ Research fellow, Dept. of Geography, Aurangabad
}

\begin{abstract}
Present study is focused on Mula Irrigation project and its impact on Irrigation element. Actually Ahmednagar district is located in rain shadow region in Maharashtra. There is not enough rainfall in the region. The Mula irrigation project is Large Scale Public Sector Irrigation Projects (LSPSIP).The Mula Dam plays major role in the study area. The data regarding the water availability of Mula Dam has been collected from Mula irrigation Department. The water of Mula Dam is being used for the purpose of agriculture, drinking, industry and livestock. The water storage capacity of Mula Dam is 26000 TMC. The agricultural development took place in the study region due to Mula Dam.
\end{abstract}

Keywords: Irrigated area, water utilization, Mula irrigation project, water storage, canal and well irrigation

\section{Introduction}

Water resources are crucial for domestic, industrial, agricultural and environmental use. By controlling water resources, a country has the ability to control economy and population. Although domestic and commercial use of water represents only a small percentage of total withdrawals and consumption, these uses have a high priority which makes resources management critical. In 1975, these use accounted for 8.5 percent of total fresh water withdrawals and 6.9 percent of consumption, in contrast, irrigation accounted for 47 percent of withdrawals and 81 percent of consumption. By the year 2000, domestic and commercial uses are expected to increase by about 30 percent $^{1}$.

Conjunctive use of surface and ground waters is fast emerging out as an important water management issue. This is because that several as existing irrigation projects suffer from inadequate supplies. It is observed that the available supply in many of the canal; systems is one forth to one third of the amount of water needed for intensive agriculture; nor it is supplied satisfactory in time. Moreover, neglect or ignorance of ground water component in irrigation planning is one of the main causes for water logging and the attendant problems of salinity in the commands. Conjunctive use aspect has a social dimension too in the sense that while surface water resources are owned by Government, the ownership of ground water is vested with the owner of the land. The problems arise when the farmers are reluctant to go for ground water despite its availability, as it involves investment which they cannot afford; instead prefer canal water as it is available cheaply. As a result, the tail Enders (usually the unfortunate poor cousins of the farmer in the upper riches) position becomes desperate as they are deprived of their share of water to raise the crop.
All these stress that where surface water and ground water coexist, it is essential to develop a strategy for their conjunctive use governed by economic consideration pertaining to the region.

The conjunctive use of water resources can be achieved through full use of surface waters supplemented by ground water or the direct use of ground water during the periods of low canal water supplies or canal closures. This would also facilitate irrigation with poor quality (saline) ground water after diluting with good quality surface water ${ }^{2}$.

\section{Significance of the Study Area}

Water has an economic value in all its competing uses and should be recognized as an economic good. In future Agriculture will not get water free of charge as it did in the past. Farmers will have to pay for the water, and cost will be increasing steadily over the years to come.

During the recent decade, growth in crop productivity in irrigated areas has slowed and competition for water for nonagricultural use has increased ${ }^{3}$.

\section{Objective}

- To Study the water utilization ofMula irrigation project in Ahmednagar District.

- To Study the impact of Mula irrigation project on irrigation area by surface (canal) and well irrigation. 


\section{International Journal of Science and Research (IJSR)}

ISSN (Online): 2319-7064

Index Copernicus Value (2013): 6.14 | Impact Factor (2014): 5.611

\section{Data Collection Research Methodology}

The Present research work is based on secondary sources of data. The data collected and used for the period 2000-2011. The secondary data is obtained from socio-economic review, District Statistical Abstract of Ahmednagar district, Mulairrigation Department, Ahmednagar. The collected data is processed and tabulated and then suitable graphs have been constructed and interpreted.

\section{Study Region}

Ahmednagar is the biggest district of Maharashtra in terms of area. Ahmednagardistrict is situated between $18^{\circ} 2^{\prime}$ and $19^{\circ} 9^{\prime}$ north latitudes and $73^{\circ} 9^{\prime}$ and $75^{\circ} 5^{\prime}$ east longitudes. The district is compact in shape. It is bounded on the north by Nasik district; on the north-east by Aurangabad district of Marathwada division, on the east by Beed district; Osmanabaddistrict; on the south by Solapur district; and on the south-west by of Thana district. Total geographical area of the district is 17,035 square $\mathrm{km}$.

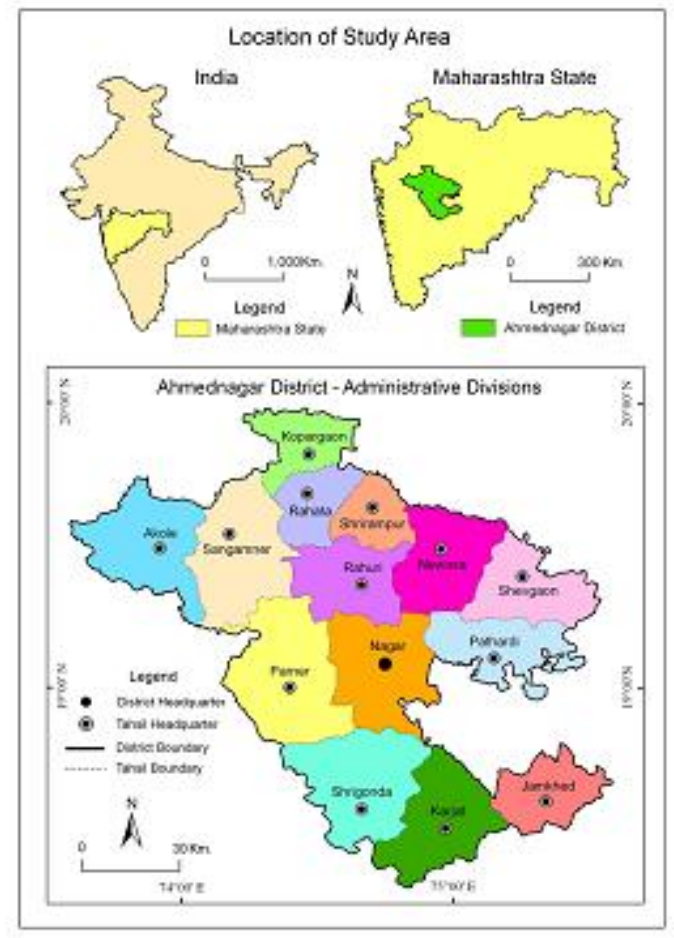

Mula dam is located at $19^{0} 20^{\text {ec }}$ to $19^{0} 35^{\text {ec }} \mathrm{N}$ latitude and $74^{0} 25^{\text {ec }}$ to $74^{0} 36^{\text {ce }} \mathrm{E}$ longitude. The dam is constructed(1971) on river Mula a tributary of river Godavari at Rahuri, district Ahmednagar.The water storage capacity of the dam is 26000 TMC. Catchments area is about $2275 \mathrm{sq} \mathrm{km}$ and it experiences an average rainfall $58 \mathrm{~cm}$. Maximum depth is $67.97 \mathrm{~m}$. The dam water has been used for drinking and irrigation by the people of Ahmednagar city and districts ${ }^{4}$.

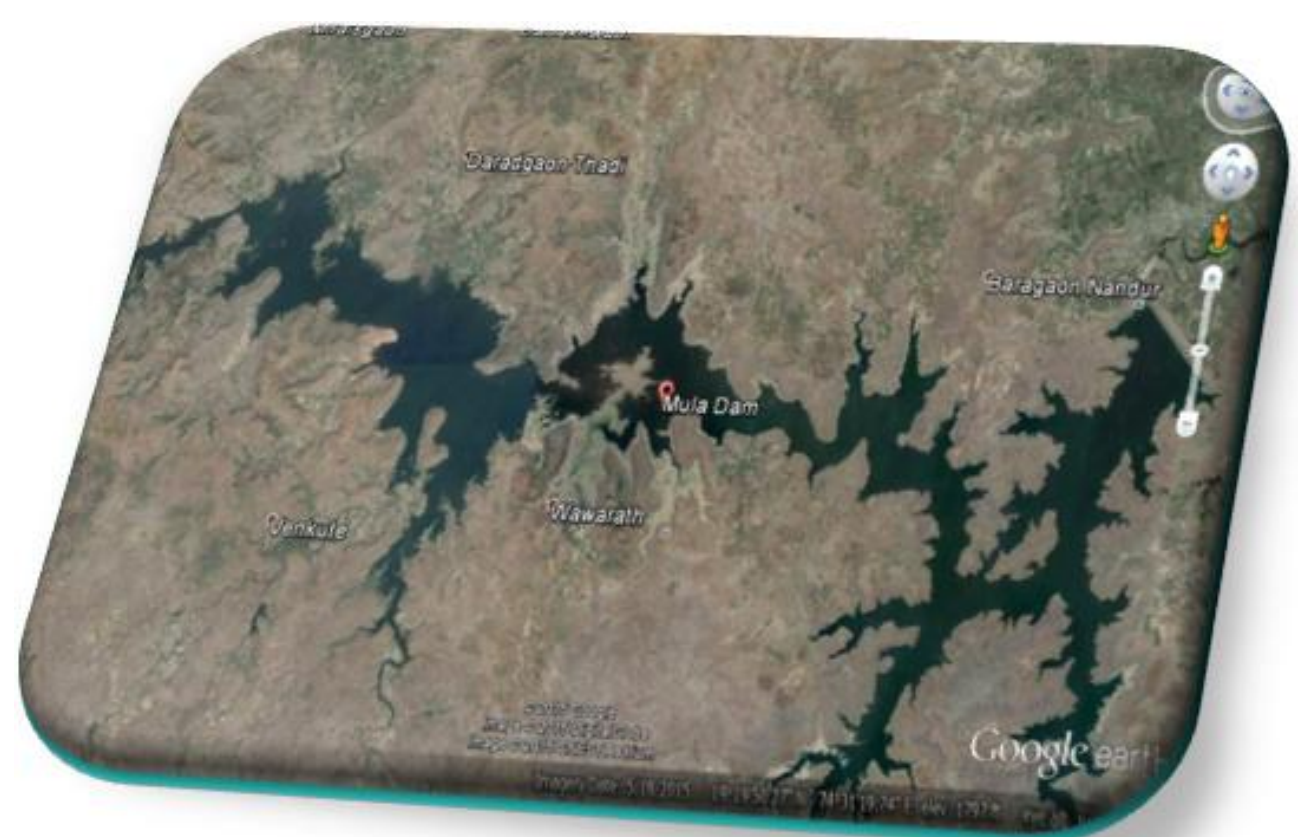

Figure 1: Showing satellite image of Mula dam $\left(19.3293065^{\circ} \mathrm{N}, 74.5295548^{\circ} \mathrm{E}\right)$ (Source- Google earth) 


\section{International Journal of Science and Research (IJSR) \\ ISSN (Online): 2319-7064}

Index Copernicus Value (2013): 6.14 | Impact Factor (2014): 5.611

\section{Discussion}

The world commision on Dams (in london) states that " Dams have made an important and significant contribution to human development, and the benefits derived from them have been considerable ${ }^{7}$."

Canal Irrigation in Maharashtra is mostly provided by Large Scale Public Sector Irrigation Projects (LSPSIP).LSPSIP in Maharashtra are Water-Infrastructure-Systems [WIS] which provide water not only for irrigation but even for nonirrigation purposes. These systems are highly complex Public Distribution Systems [PDS] comprising of several TechnoSocio-Economic-Legal [TSEL] processes expected (but not designed) to simultaneously achieve multiple $\&$ at times, even competitive / conflicting objectives ${ }^{8}$.
Table 1: Water Utilization of MulaDam(2001-11)

(Water- In TMC)

\begin{tabular}{|c|c|c|c|c|c|c|}
\hline $\begin{array}{l}\text { Sr. } \\
\text { No }\end{array}$ & Year & $\begin{array}{c}\text { Usable } \\
\text { water } \\
\text { storage of } \\
15 / 10\end{array}$ & $\begin{array}{c}\text { Usable } \\
\text { water } \\
\text { storage } \\
\text { of } 15 / 03\end{array}$ & $\begin{array}{l}\text { Evapo- } \\
\text { ration }\end{array}$ & \begin{tabular}{|c|}
$\begin{array}{r}\text { Utiliza } \\
\text { Wa } \\
\text { (in perc }\end{array}$ \\
Drinking \\
and \\
Industry
\end{tabular} & $\begin{array}{l}\text { ation of } \\
\text { ater } \\
\text { centage) } \\
\text { Irrigation }\end{array}$ \\
\hline 1 & 2001-02 & 556.95 & 290.59 & 53.40 & 13.13 & 86.87 \\
\hline 2 & $2002-03$ & 457.94 & 106.34 & 50.24 & 15.77 & 84.23 \\
\hline 3 & 2003-04 & 264.68 & 113.11 & 46.27 & 23.00 & 77.00 \\
\hline 4 & 2004-05 & & 285.13 & 66.26 & 07.74 & 92.26 \\
\hline 5 & $2005-06$ & 608.82 & 232.99 & 55.64 & 09.03 & 90.97 \\
\hline 6 & 2006-07 & 608.82 & 351.86 & 59.60 & 07.69 & 92.31 \\
\hline 7 & $2007-08$ & 608.82 & 284.56 & 65.82 & 05.85 & 94.15 \\
\hline 8 & 2008-09 & 608.82 & 314.74 & 62.57 & 07.12 & 92.88 \\
\hline 9 & 2009-10 & 338.10 & 306.73 & 55.70 & 09.19 & 90.81 \\
\hline 10 & $2010-2011$ & 603.07 & 472.77 & 68.30 & 08.64 & 91.36 \\
\hline
\end{tabular}

(Source: Mula Irrigation Department, Ahmednagar.)

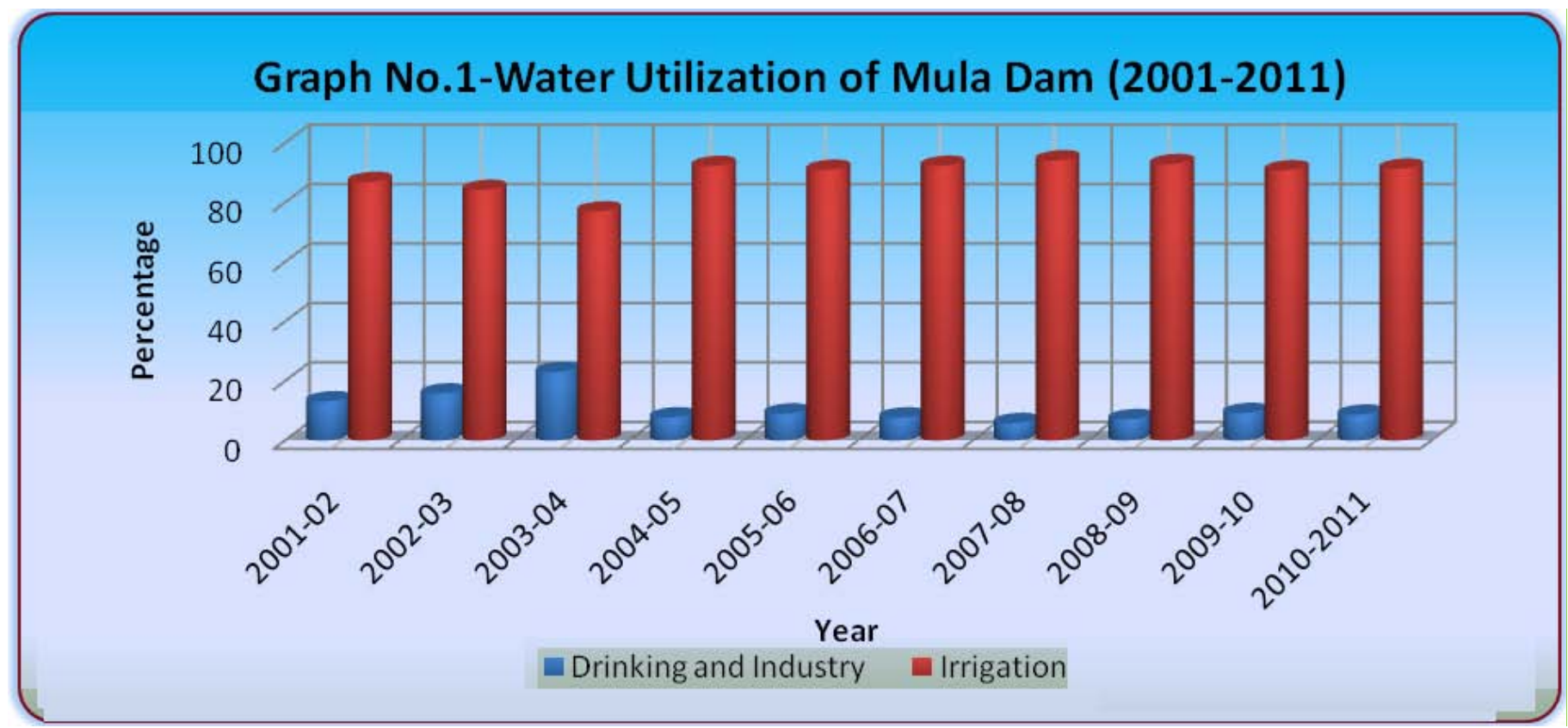

Table no.1 reveals the water utilization of Mula irrigation project during the period 2001-2011.Usable water storage of the month of October was higher than March due to the monsoon season. In 2003-04 and 2009-10 there was very low water storage in Mula irrigation project that was about 264.68 TMC and 338.07TMC respectively. From the year 2004 to 2009 the constant water storage was about 608.82 TMC. In the year 2003-2004 drinking and industrial use of water was increased by about 23.00 percent and 77 percent water was used for irrigation. During the years 2004-05, 2007-08 utilization of water for irrigation was high \& that was 92.26 , 94.15 percent respectively. The graph shows that, near by 90 percent water was used for irrigation and only 10 percent water for drinking and industrial purpose.Evaporation rate in the year 2010-2011was maximum\& that was 68.30 percent and in 2003-2004 it was the lowest in the decade that was 46.27 percent.
Table 2: Irrigated Area by Mula Dam (Area- In percent)

\begin{tabular}{|c|c|c|c|}
\hline $\begin{array}{c}\text { Sr. } \\
\text { No. }\end{array}$ & Year & $\begin{array}{c}\text { Surface (Canal) } \\
\text { Irrigated Area }\end{array}$ & $\begin{array}{c}\text { Well Irrigated } \\
\text { Area }\end{array}$ \\
\hline $\mathbf{1}$ & $2001-02$ & 53.47 & 46.53 \\
\hline $\mathbf{2}$ & $2002-03$ & 57.31 & 42.69 \\
\hline $\mathbf{3}$ & $2003-04$ & 59.56 & 40.44 \\
\hline $\mathbf{4}$ & $2004-05$ & 50.70 & 49.30 \\
\hline $\mathbf{5}$ & $2005-06$ & 50.36 & 49.64 \\
\hline $\mathbf{6}$ & $2006-07$ & 39.12 & 60.88 \\
\hline $\mathbf{7}$ & $2007-08$ & 53.39 & 46.61 \\
\hline $\mathbf{8}$ & $2008-09$ & 49.62 & 50.38 \\
\hline $\mathbf{9}$ & $2009-10$ & 64.95 & 35.05 \\
\hline $\mathbf{1 0}$ & $2010-2011$ & 55.53 & 44.47 \\
\hline
\end{tabular}

(Source: Computed by author from MulaIrrigation Department, Ahmednagar.) 


\section{International Journal of Science and Research (IJSR)}

ISSN (Online): 2319-7064

Index Copernicus Value (2013): 6.14 | Impact Factor (2014): 5.611

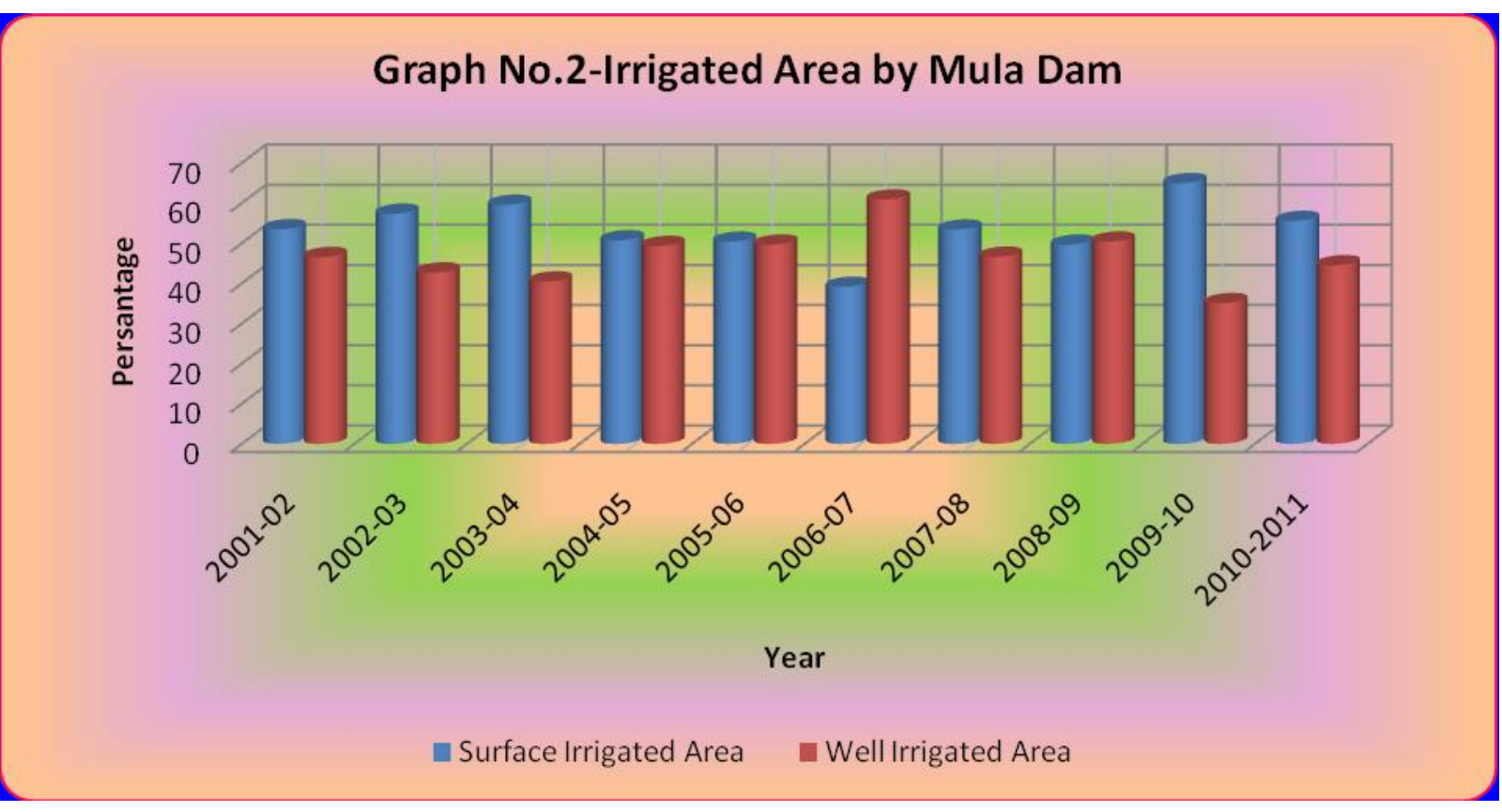

Table No. 2. Shows that irrigated area under canal and well irrigation sources are continuously increasing by Mula irrigation project. As a result, the percentage of irrigated area had increased under canal irrigation by Mula irrigation project. The surface irrigated area was increased in year 200304 and 2009-10 that was 59.56 and 64.95 percent respectively. Well irrigated area was increased in the year 2006-07 upto 60.88 percent and surface irrigated area was only 39.12 percent in same year.The graph No. 2 clearly indicates that, the area of under Mula irrigation project has very high potential of irrigation facility.

\section{Conclusion}

1) Water utilization is low for drinking and industrial purpose and that is between 5 to 23 percent during the research work.

2) Surface irrigation has strong potential due to Mula irrigation project.

3) The lowest water storage was observed in the year 200910.

4) From the year 2004 to 2009 the water storage was constant of Mula irrigation project.

5) In the year 2006-07 the well irrigated area was increased.

6) Such multipurpose projects immensely important to contribute the development of agriculture, industry and quality of drinking water which will automatically lead to overall development of the region.

\section{References}

[1] Nishi K. Dixit (2008), „Water Shortage A Global Problem' Vista International Publishing House Delhi, p. 56, 196.

[2] P. Balakrishnan (1986) 'Issues in Water Resources Development and Management and the role of remote sensing' Indian Space Research OrganisationBanglore, $\mathrm{p}$. 32,33 .

[3] Narasaiah M. L. (2010) 'Dams and Irrigation', Discovery Publishing House New Delhi, p. 38.

[4] Dams of India, 2009, Ahmednagar Gazetteers, quoted in AherM.S.andSonawane P.A.(2015),, Fish Fauna of Mula River at Mula Dam Reservoir, Rahuri (M.S.), India'Journal of Basic Sciences, Special Issue on BioIPPF, 41-44.

[5] satellite image of Mula dam $\left(19.3293065^{\circ} \mathrm{N}\right.$, $\left.74.5295548^{\circ} \mathrm{E}\right)$ (Source- Google earth)

[6] Mula Irrigation Department, Ahmednagar.

[7] Narasaiah M. L. (2010) ,Dams and Irrigation "e, Discovery Publishing House New Delhi, p. 16.

[8] PradeepPurandare (2012) „Canal Irrigation in Maharashtra: Present Statuse Dams River and People. P. 17.People, Rivers \& People |Dams, Rivers \& People |Dams, Rivers \& People | 